\title{
POPULATION STATUS OF ORIBI (OUREBIA OUREBI ZIMMERMANN, 1783) IN MAZE NATIONAL PARK, SOUTHERN ETHIOPIA
}

\author{
Wondimagegnehu Tekalign* and Afework Bekele ${ }^{2}$ \\ Department of Biology, College of Natural and Computational Sciences, \\ Wolaita Sodo University, PO Box 138, Wolaita Sodo, Ethiopia
}

\begin{abstract}
The population status of oribi (Ourebia ourebi Zimmermann, 1783) was carried out in the newly established Maze National Park, Ethiopia for two consecutive years (October 2009 to December 2011). A total count method was employed based on silent detection method in an area of $220 \mathrm{~km}^{2}$. A total of 894 and 1103 individuals were counted during the two consecutive years, respectively. Seasonal variation was significantly different with more individuals during the dry season than the wet season $(\mathrm{p}<0.05)$. The density of oribi over the whole area was 3.40 and 4.36 during the wet and 4.72 and 5.66 individuals per $\mathrm{km}^{2}$ during the dry seasons in both years, respectively. The study was important for future conservation measures as the oribi is the flagship species of the area.
\end{abstract}

Key words: Oribi, Population size, Density, Maze National Park, Ethiopia

\section{INTRODUCTION}

The oribi (Ourebia ourebi Zimmermann, 1783) is a graceful slender-legged, long-necked small savanna antelopes. Male has a distinctively large gland beneath the eyes and female is slightly larger and heavier than male (Smithers, 1983; Grey-Ross et al., 2009). In East Africa, the females of oribi are approximately $2 \mathrm{~kg}$ heavier than males (Skinner and Chimimba, 2007). It is the Africa's smallest grazing ungulate (Hofmann, 1989) and the largest of the dwarf antelopes in the Family Bovidae (Stuart and Stuart, 1997; Cerling et al., 2003), and the most gazelle-like of the Neotragini (Estes, 1992).

Across Africa, 13 subspecies of oribi have been described in the single species of $O$. ourebi on the basis of morphological variation in body size and colouration across the species' range and behavioural differences (Nowak, 1991; Marchant et al., 2007). Animals in East Africa appear larger and darker than the other, but this trend, and the validity of many proposed sub-species has not been tested using molecular techniques. Two of the subspecies occur in Ethiopia, O. o. montana along the Sudanese border to the western part of Ethiopia and O. o. gallarum in central Ethiopia. In Ethiopia, oribi occurs mainly within and to the west of the Rift Valley. It survives quite widely in open habitats within its historical range, including some settled areas (East, 1999). East (1999) described the occurrence of oribi in areas such as Senkele Wildlife Sanctuary, Mago, Gambella, Omo and Maze National Parks. Timer (2003)

*Corresponding author: E-mail: <wondimagegnehubeyene@gmail.com>. ${ }^{2}$ Departments of Zoological Sciences, College of Natural Sciences, Addis Ababa University, PO Box 1176 Addis Ababa, Ethiopia. 
reported the existence of individuals of oribi in Maze National Park. However, due to its shyness, it is not easy to observe. It may be more common in Ethiopia and other African countries than is generally realized.

No systematic study has been conducted to estimate the number of oribi in the Maze National Park. However, it was repeatedly reported by scouts of the Park and other investigators that they are common and unusually abundant inside the Park area (Timer, 2003). The reasons why this species is more abundant in the area has not been scientifically justified. Obtaining adequate data is important for conservation of the species. Oribi acts as a flagship species for the conservation of important grassland areas like Maze National Park due to its grassland dependence (Marchant et al., 2007). Therefore, the study on the population status of oribi will be critical and important in this newly established and future wildlife potential of the Park.

\section{MATERIAL AND METHODS}

The study was carried out from October 2009 to December 2011 in Maze National Park, Ethiopia. It is situated between 06 $03^{\prime}$ and 06 $30^{\prime} \mathrm{N}$ latitude and $37^{\circ} 07^{\prime}$ and $37^{\circ} 20^{\prime} \mathrm{E}$ longitude. The Park was established by the regional state in 2005. It is about $485 \mathrm{~km}$ southwest of the capital Addis Ababa. The altitude ranges from 998 to $1200 \mathrm{~m}$ above sea level and covers an area of $220 \mathrm{~km}^{2}$. The annual rainfall varies between $843.8 \mathrm{~mm}$ and $1375.3 \mathrm{~mm}$. The lowest temperature recorded was $17.6^{\circ} \mathrm{C}$ and the highest $33.9^{\circ} \mathrm{C}$ measures in the time period.

Total count method was applied based on silent detection procedure as adopted by Sutherland (1996), and Refera and Bekele (2006). Twenty-four censuses were carried out from December 2009 to November 2010, Year I and December 2010 to November 2011, Year II, both during the wet and dry seasons, consecutively. Counting was carried out by both naked eyes and/or using a pair of binoculars. Census was conducted when the oribi was most active and with good visibility during 08:00 to 11:00 hours in the morning and 15:00 to 18:00 hours in the afternoon. Each total count was completed within three hours in a day using ten or more well trained Park scouts. To alleviate the problem of double counting eight selected blocks were designed based on natural and artificial boundaries. The size of each of the eight blocks was variable (Block $1=26.4 \mathrm{~km}^{2}$, Block $2=21.9 \mathrm{~km}^{2}$, Block $3=34.2 \mathrm{~km}^{2}$, Block $4=$ $20.7 \mathrm{~km}^{2}$, Block $5=14.9 \mathrm{~km}^{2}$, Block $6=28.5 \mathrm{~km}^{2}$, Block $7=41.1 \mathrm{~km}^{2}$ and Block $8=32.3 \mathrm{~km}^{2}$ ). The distance between consecutive transects varied depending on the vegetation cover. The seasonal variation and block differences were compared by using Chi-Square and one-way ANOVA tests. The multiple 
comparisons of Tukey-test were also applied and the mean density was determined using one-sample t-test.

\section{RESULTS AND DISCUSSION}

A total mean of 894 and 1103 oribi individuals were counted during the census period at Year I and Year II, consecutively in Maze National Park. The maximum mean total record during the census was 1039 and 1246 individuals during the dry seasons (I and II) and the minimum was 748 and 860 in the wet seasons (I and II), respectively. So, the maximum number of oribi counted (1246) during the whole census period was during the dry season II and the lowest (748) in the wet season I. The seasonal variation of oribi was significantly different with more individuals during the dry season than the wet season, both at Year I $(x 2=47.387, \mathrm{df}=1, \mathrm{p}<0.001)$ and at Year II $(\mathrm{x} 2=37.079, \mathrm{df}=1, \mathrm{p}<0.001)$ (Table 1).

Table 1 Total count of oribi during wet and dry seasons for the two years (B=block)

\begin{tabular}{llllllllll}
\hline Season & B-1 & B-2 & B-3 & B-4 & B-5 & B-6 & B-7 & B-8 & Total \\
\hline Dry I & 61 & 306 & 268 & 115 & 24 & 47 & 22 & 196 & 1039 \\
Dry II & 202 & 338 & 156 & 215 & 70 & 87 & 45 & 133 & 1246 \\
Wet I & 76 & 221 & 124 & 55 & 40 & 82 & 42 & 108 & 748 \\
Wet II & 182 & 106 & 116 & 163 & 41 & 79 & 132 & 141 & 960 \\
\hline
\end{tabular}

The highest number of oribi individuals was counted at Block 2 both during the wet (221) and dry seasons (306) while the lowest at Block 5 (40) during the wet season and Block 7 (22) during the dry season at Year I. However, at Year II, the highest number of oribi was counted at Block 1 (182) during the wet season and Block 2 (338) during the dry season while less number of individuals was counted at Block 5 (41) during the wet season and Block 7 (45) during the dry season.

The mean density of oribi over the whole study area during Year I was 3.40 and 4.72 individuals per $\mathrm{km}^{2}$, while during Year II, it was 4.36 and 5.66 individuals per $\mathrm{km}^{2}$ during wet and dry seasons, respectively. The annual mean total density of oribi in the blocks estimated during Year I was $4.06(4.30 \pm 1.24)$ per $\mathrm{km}^{2}$ and it was 5.01 (5.45 \pm 1.06$)$ individuals per $\mathrm{km}^{2}$ during Year II. There is a significant difference in density among the blocks of the whole study area both at Year I $(t=3.468, d f=7, p<0.05)$ and Year II $(t=5.144, d f=7, p<0.05)$. There was a statistically significant difference in density among the blocks both during the wet $(3.65 \pm 0.96)(t=3.802, d f=7, p<0.05)$ and the dry $(4.94 \pm 1.58)(t=3.129$, $\mathrm{df}=7, \mathrm{p}<0.05$ ) seasons during the first year. During Year II, there was also a 
significant difference in the density estimates of oribi among the blocks both during the wet $(4.51 \pm 0.68)(\mathrm{t}=6.601, \mathrm{df}=7, \mathrm{p}<0.05)$ and dry $(6.37 \pm 1.64)$ $(\mathrm{t}=3.896, \mathrm{df}=7, \mathrm{p}<0.05)$ seasons. Among the blocks, the highest density was obtained from Block 2 during the dry season both during Year I $\left(13.97 / \mathrm{km}^{2}\right)$ and Year II $\left(15.43 / \mathrm{km}^{2}\right)$. However, the lowest density of oribi was observed form Block 7 during the same dry season both at Year I $\left(0.54 / \mathrm{km}^{2}\right)$ and Year II $\left(1.09 / \mathrm{km}^{2}\right)$ (Fig. 1).

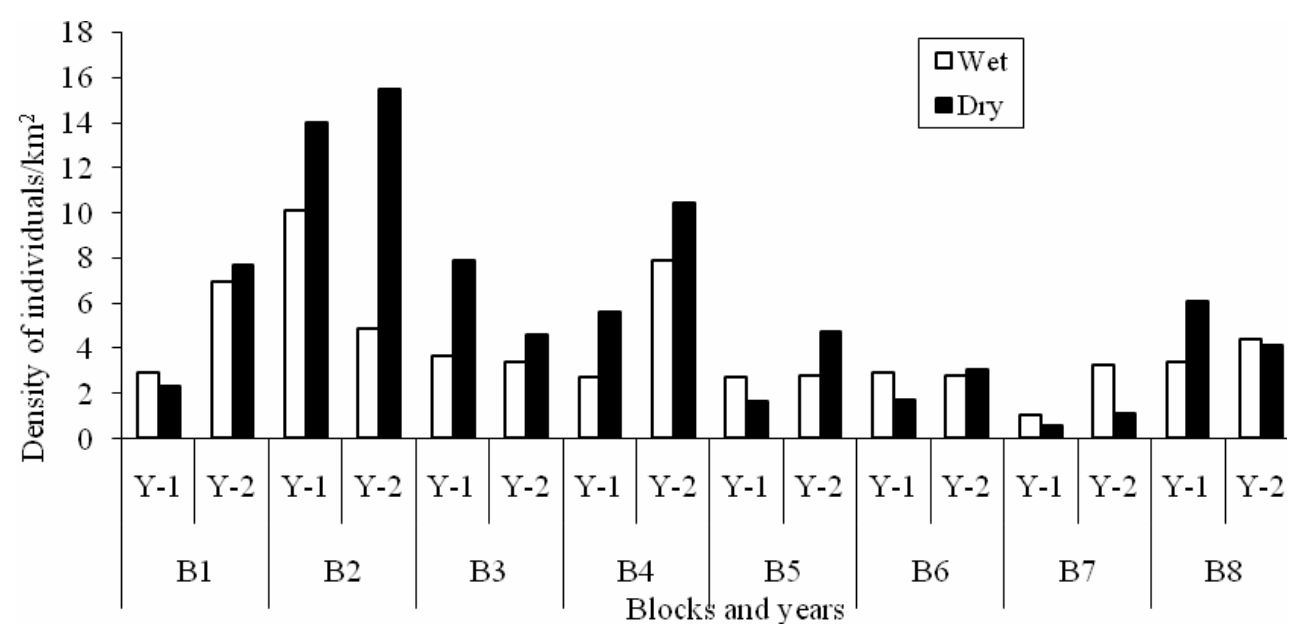

Fig 1 Density estimates of oribi in different blocks during the wet and dry seasons for Year I and II $(\mathrm{B}=$ Block, $\mathrm{Y}=$ year $)$

Many of Africa's conservation areas including the newly established Maze National Park in Ethiopia are experiencing large decline in their ungulate populations due to various factors (Fynn and Bonyongo, 2010). Mallon and Kingswood (2001) described that in addition to the many factors contributing to the decline of antelopes, details of distribution and status of many taxa are uncertain, and little is known of the ecology of several species. The absence of adequate survey data to monitor wildlife populations prevents timely management and conservation decisions that could ultimately save the species. So, it is mandatory to assess the population status of oribi to take future conservation measures, as this is a keystone species of the Park. Direct total count technique is the most suitable method in such a small area like the Maze National Park. In many ungulates, obtaining high number is usual during the wet season. However, in oribi increase in number was observed during the dry season. This might be due to the tendency to spend a large proportion of their day time lying in the long grass. At the same time, the tall grass in the area might have reduced visibility leading to reduction in number. Studies on the population of oribis revealed that they mostly occur close to rocks during the dry 
season and long grasses in the wet season (Mduma and Sinclair, 2008). So, achieving an accurate count of the animals during the wet season was difficult. At the same time, recruitment during the wet season might also have led to increase in number in the next dry season.

The difference in density of individuals at different blocks in both years might be related to the accessibility and palatability of the grasses. The present result indicates that savanna grassland and grasslands with scattered trees harboured higher number of oribi than the bushland and riverine forest habitats. Most of the time, oribis were observed in the grasslands with scattered tree habitats that were regularly burned. The results showed high number of oribi during the dry season when the new fresh grass sprouts due to the burning of the grassland by the locals. Livestock enter the Park for grazing also had access the highest number and reaching peak during the dry season. Estes (1992) described that fire sweeps through long grasslands every dry season, leaving little and sometimes no cover left in the oribi territories for concealment against predators. Oribi were observed highly favouring and shift immediately from unburned to burned grasses to get newly sprouted grass. In addition, if the grass becomes tall it hides, so the oribi avoid excessively longer grasses. Probably, this might be the other reason for the variation of individual density/unit area in different blocks of the study area.

The variation in annual mean total density might be due to accessibility of palatable fresh grass, movement of the local community and their livestock, and vulnerability of the area to predators. Belovsky (1986) elaborated that population densities of a number of herbivore species depend upon the biomass of plants in the environment that satisfy the minimum characteristics sought by the herbivore. Goldspink et al. (2002) recorded that the mean density estimates of oribi population from the two contrasting sites in Zambia were 2.02 and 1.90 per $\mathrm{km}^{2}$. Goldspink et al. (2002) described that the population density of oribi in different parts of Africa vary from $2 / \mathrm{km}^{2}$ up to $10 / \mathrm{km}^{2}$ registered from the Serengeti National Park, Tanzania. The present estimate of population density at Maze National Park, Ethiopia was high compared to the data from the Bangweulu and Kafue areas, Zambia but low compared to the Serengeti National Park, Tanzania.

During the study period high pressure on Park resources from the local communities living in the periphery and people coming from far distant areas were observed. There was also a large number of livestock grazing along with oribi and other wildlife of the Park. These pressure in and around the Park might result in severe degradation of the environment and loss of wildlife and their habitats in the future. So, the Park management and the concerned 
governmental bodies should pay attention and take urgent conservation measures to keep up the present status of the flagship species of the area.

Acknowledgements: We would like to thank Parks and Tourism Bureau of Southern Ethiopia and all staff members of Maze National Park for their help and cooperation. We sincerely thank Addis Ababa University for providing fund to conduct this research.

\section{LITERATURE CITED}

BELOVSKY, G.E. 1986. Generalist herbivore foraging and its role in competitive interactions. Integr. Comp. Biol. 26: 51-69.

CERLING, T.E., HARRIS, J.M. and PASSEY, B.H. 2003. Diets of east African bovidae based on stable isotope analysis. J. Mamm. 84: 456-470.

EAST, R. 1999. African Antelope Database 1998. IUCN/SSC Antelope Specialist Group. IUCN, Gland, Cambridge, 434 pp.

ESTES, R.D. 1992. The Behavior Guide to African Mammals. University of California Press, Los Angeles, $634 \mathrm{pp}$.

FYNN, R.W.S. and BONYONGO, M.C. 2010. Functional conservation areas and the future of Africa's wildlife. Afr. J. Ecol. 49: 175-188.

GOLDSPINK, C.R., HOLLAND, R.K., SWEET, G. and STEWART, L. 2002. A note on group sizes of oribi (Ourebia ourebi Zimmermann, 1783) from two contrasting sites in Zambia, with and without predation. Afr. J. Ecol. 40: 372-378.

GREY-ROSS, R., DOWNS, C.T. and KIRKMAN, K. 2009. Is use of translocation for the conservation of subpopulations of oribi Ourebia ourebi (Zimmermann) effective? Case study. Afr. J. Ecol. 47: 409-415.

HOFMANN, R.R. 1989. Evolutionary steps of ecophysiological adaptation and diversification of ruminants: a comparative view of their digestive system. Oecologia 78: 443-457.

MALLON, D.P. and KINGSWOOD, S.C. 2001. Antelopes. Part 4: North Africa, the Middle East, and Asia. Global Survey and Regional Action Plans. SSC Antelope Specialist Group. IUCN, Gland, Switzerland and Cambridge, UK. viii +260 pp. Available at http://www.iucn.org.

MARCHANT, A., RUSHWORTH, I. and McCANN, K. 2007. KwaZulu-Natal (KZN) Oribi (Ourebia ourebi) Conservation Plan. Oribi Working Group-Endangered Wildlife Trust, Johannesburg, 31 pp.

MDUMA, S.A.R. and SINCLAIR, A.R.E. 2008. The function of habitat selection by oribi in Serengeti, Tanzania. Afr. J. Ecol. 32: 16-29.

NOWAK, R.M. 1991. Walker's Mammals of the World. The Johns Hopkins Press Ltd., London, 1455 pp.

REFERA, B. and BEKELE, A. 2006. Population status and structure of Swayne's Hartebeest (Alcelaphus buselaphus swaynei) in Mazie National Park, Ethiopia. Int. J. Ecol. Environ. Sci. 32: 259-264.

SKINNER, J.D. and CHIMIMBA, C.T. 2007. The Mammals of Southern Africa Sub-region. Cambridge University Press, Cambridge, 698 pp.

SMITHERS, R.H.N. 1983. The Mammals of the Southern Africa Sub-region. University of Pretoria, Pretoria, $760 \mathrm{pp}$.

STUART, C.T. and STUART, M.D. 1997. Field Guide to the Large Mammals of Africa. Struik Publishers, Cape Town, 272 pp. 
SUTHERLAND, W.J. 1996. Ecological Census Technique. A Handbook Cambridge University Press, London, $336 \mathrm{pp}$.

TIMER, G. 2003. Technical Report on the Biodiversity of Mazie National Park, Arbaminch. Unpublished document, Southern, Nations, Nationalities and Peoples' Regional State (SNNPRS) tourism and parks office, Hawasa, Ethiopia, 69 pp.

(Manuscript received on 6 June 2012; revised on 24 December 2013) 